\author{
KS. DARIUSZ WALENCIK \\ Uniwersytet Opolski \\ 0000-0002-1027-3980
}

\title{
KURIA DIECEZJALNA UCZESTNIKIEM POWSZECHNEGO OBROTU PRAWNEGO?
}

Treść: - Uwagi wprowadzające. - 1. Definicja. - 2. Osoba prawna, jednostka organizacyjna, podmiot ustawowy, podmiot prawnopodatkowy, aparat pomocniczy. - 3. Zdolność prawna, zdolność do czynności prawnych, zdolność sądowa i procesowa. - 4. Kuria diecezjalna jako organ? - 5. Kuria diecezjalna jako pracodawca. - 6. Kuria diecezjalna jako płatnik, wyręczyciel. - Wnioski.

\section{Uwagi wprowadzające}

Związki wyznaniowe i ich jednostki organizacyjne, wypełniając swoje funkcje religijne ${ }^{1}$ na terytorium Rzeczypospolitej Polskiej, stają się także uczestnikami obrotu prawnego regulowanego przez przepisy prawa polskiego. Jednocześnie - zgodnie z zasadą autonomii i niezależności ${ }^{2}$ - działają one przede wszystkim na podstawie przepisów prawa wewnętrznego (kanonicznego) danej wspólnoty religijnej. Ten dualizm prawny generuje w praktyce administracyjnej i orzeczniczej ${ }^{3}$,

${ }^{1}$ Por. art. 19 ust. 2 w związku z art. 11 ust. 2 ustawy z dnia 17 maja 1989 r. o gwarancjach wolności sumienia i wyznania (t.j. Dz. U. z 2017 r., poz. 1153).

${ }^{2}$ Por. art. 25 ust. 3 Konstytucji Rzeczypospolitej Polskiej z dnia 2 kwietnia 1997 r. (Dz. U. Nr 78, poz. 483 z późn. zm.).

${ }^{3}$ Zob. zwłaszcza wyrok SN z dnia 12 marca 1997 r., II CKN 24/97, LEX nr 80725; wyrok SN z dnia 27 lipca 2000 r., IV CKN 88/00, OSP 2003, z. 9, s. 491-492; wyrok SN z dnia 24 marca 2004 r., IV CK 108/03, OSNC 2005, nr 4, s. 48-60; wyrok SN z dnia 2 lutego 2005 r., IV CK 480/04, „Przegląd Prawa Wyznaniowego” 2009, t. 1, 
ale również w poglądach doktryny wiele wątpliwości i trudności ${ }^{4}$.

s. 203-206; wyrok SN z dnia 17 lutego 2005 r., IV CK 582/04, LEX nr 176007; uchwała SN z dnia 19 grudnia 2008 r., III CZP 122/08, OSP 2010, z. 2, s. 114-120; postanowienie SN z dnia 12 stycznia 2011 r., I CSK 182/10, OSP 2011, z. 12, s. 885-889; wyrok NSA z dnia 3 lipca 2000 r., II SA 1128/99, OSP 2001, z. 12, s. 602-605; wyrok NSA z dnia 19 września 2000 r., III SA 1411/00, LEX nr 47198; wyrok NSA z dnia 8 stycznia 2008 r., II GSK 286/07, OSP 2009, z. 2, s. 120-123; wyrok NSA z dnia 5 lutego 2016 r., II OSK 1631/14, ONSAiWSA 2017, nr 2, s. 103-112; wyrok Sądu Antymonopolowego z dnia 23 kwietnia 2001 r., XVII Ama 49/00, Dz. Urz. UOKiK 2001, z. 1, poz. 11; wyrok Sądu Ochrony Konkurencji i Konsumentów z dnia 12 stycznia 2006 r., XVII Ama 105/04, Dz. Urz. UOKiK 2006, z. 2, poz. 28.

${ }^{4}$ Zob. zwłaszcza W. Brzozowski, Glosa do wyroku NSA z dnia 8 stycznia 2008 r. (II GSK 286/07), Przegląd Sądowy 2010, nr 1, s. 152-159; A. Gill, Glosa do wyroku Naczelnego Sądu Administracyjnego z dnia 3 lipca 2000 r. (II SA 1128/99), Orzecznictwo Sądów Polskich [dalej: OSP] 2001, z. 12, s. 605-608; A. JANUCHOwski, Skuteczność prawa kanonicznego w zakresie reprezentacji osób prawnych Kościoła katolickiego, Rejent 2007, nr 9, s. 49-67; TENżE, Wybrane zagadnienia związane z reprezentacja parafii przez proboszcza na gruncie prawa kanonicznego i polskiego, Studia z Prawa Wyznaniowego 2008, t. 11, s. 211-236; Tenże, Glosa do wyroku NSA z dnia 8 stycznia 2008 r., II GSK 286/07, OSP 2009, z. 2, s. 123-125; Tenże, Glosa do uchwały SN z dnia 19 grudnia 2008 r. (III CZP 122/08), OSP 2010, z. 2, s. 127-132; M. JASIAKIEWICZ, Glosa do wyroku Sąu Najwyższego z dnia 27 lipca 2000 r., IV CKN 88/00, Rejent 2005, nr 1, s. 122-137; J. Kuźmicka-Sulimowska, Glosa do uchwały SN z dnia 19 grudnia 2008 r. (III CZP 122/08), OSP 2011, z. 12, s. 889-894; J. KuŹMiCKA-SulimowsKA, P. MaChNikowski, Glosa do uchwały SN z dnia 19 grudnia 2008 r. (III CZP 122/08), OSP 2010, z. 2, s. 120-126; M. KRZEMIŃski, Znaczenie prawa kanonicznego dla określenia sposobu reprezentacji kościelnych osób prawnych. Glosa do wyroku SN z 27 lipca 2000 r. (IV CKN 88/00), Prawo Bankowe 2005, nr 10, s. 20-30; A. PAwLuk, Glosa do uchwały SN z dnia 19 grudnia 2008 r. (III CZP 122/08), Rejent 2010, z. 7-8, s. 138-153; M. Pietraszewski, Glosa do uchwały SN z dnia 19 grudnia 2008 r. (III CZP 122/08), Rejent 2010, z. 3, s. 211-230; M. Pietrzak, Prawo kanoniczne w polskim systemie prawnym, Państwo i Prawo 2006, z. 8, s. 16-31; M. Plisiecki, Glosa do uchwały SN z dnia 19 grudnia 2008 r. (III CZP 122/08), Rejent 2010, z. 7-8, s. 154-159; Tenże, Wyznaniowa osoba prawna w prawie polskim, Warszawa 2013, s. 156-171; A. RĄPAŁA, Wybrane problemy stosowania prawa wewnętrznego związków wyznaniowych w sprawach majątkowych, w: Standardy bezstronności światopoglądowej władz publicznych, red. A. Mezglewski, A. Tunia, Lublin 2012, s. 173-186; G. RADEcKi, Organy osób prawnych Kościoła katolickiego w Polsce (na styku prawa kanonicznego i prawa cywilnego), Rejent 2003, nr 7/8, s. 127-155; TenżE, Glosa do wyroku Sądu Najwyższego z dnia 27 lipca 2000 r. (IV CKN 88/00), OSP 2004, z. 5, s. 246-249; TENżE, 
Różnego rodzaju wątpliwości wynikają chociażby z potrzeby, zakresu, a zwłaszcza z jednoznacznego wskazania podstaw prawnych dla stosowania prawa wewnętrznego związków wyznaniowych w państwowym porządku prawnym. Spore trudności sprawia np. określenie przez osoby trzecie charakteru prawnego podmiotu, będącego stroną danej czynności prawnej, co przekłada się na pewność obrotu. Stąd

Glosa do wyroku z dnia 24 marca 2004 r. (IV CK 108/03), Przegląd Sądowy 2006, nr 1, s. 135-140; B. Rakoczy, Glosa do wyroku Naczelnego Sadu Administracyjnego $z$ dnia 3 lipca 2000 r. (II SA 1128/99), OSP 2002, z. 7-8, s. 360-363; TenżE, Glosa do wyroku Sądu Najwyższego z dnia 27 lipca 2000 r. (IV CKN 88/00), OSP 2003, z. 9, s. 492-495; Tenże, Glosa do wyroku Sądu Antymonopolowego $z$ dnia 23 kwietnia 2001 r. XVII Ama 49/00, Przegląd Sądowy 2004, z. 7-8, s. 271-278; Tenże, Glosa do wyroku Sądu Najwyższego z dnia 24 marca 2004 r., IV CK 108/03, Rejent 2005, nr 11, s. 131-144; Tenże, Glosa do wyroku SO w Warszawie - Sąd Ochrony Konkurencji i Konsumentów z 12.01.2006 r., XVII Ama 105/04, Rejent 2007, z. 7/8, s. 211-217; TenżE, Glosa do wyroku NSA $z$ dnia 8 stycznia 2008 r., II GSK 286/07, OSP 2009, z. 2, s. 125128; Tenże, Glosa do wyroku SN z dnia 17 lutego 2005 r., IV CK 582/04, Gdańskie Studia Prawnicze - Przegląd Orzecznictwa 2009, nr 2, s. 159-164; TenżE, Glosa do wyroku Sądu Najwyższego z dnia 2 lutego 2005 r., IV CK 480/04, Przegląd Prawa Wyznaniowego 2009, t. 1, s. 206-216; TENżE, Prawo kanoniczne w orzecznictwie sądów polskich, w: Prawo wyznaniowe w Polsce (1989-2009). Analizy - dyskusje - postulaty, red. D. Walencik, Katowice - Bielsko-Biała 2009, s. 275-285; Tenże, Glosa do uchwaty SN z dnia 19 grudnia 2008 r. (III CZP 122/08), Przegląd Prawa Wyznaniowego 2011, t. 3, s. 95-102; A. RzEPECKI, Funkcjonowanie prawa kanonicznego w polskim porzadku prawnym - zarys tematu, Acta Erasmiana 2013, t. 5 Varia, s. 163 -184; P. STANisz, Proboszcz jako reprezentant parafii rzymskokatolickiej w stosunkach majątkowych, w: Prawo państwowe a prawo wewnętrzne związków wyznaniowych. Pamiętnik VII Zjazdu Katedr i Wykładowców Prawa Wyznaniowego, Gniezno 11-12 IX 2010, red. K. Krasowski, M. Materniak-Pawłowska, M. Stanulewicz, Poznań 2010, s. 191--200; M. StrzaŁA, Skuteczność norm prawa kanonicznego w zakresie reprezentacji kościelnych osób prawnych w orzecznictwie Sądu Najwyższego, w: Prawo państwowe a prawo wewnętrzne związków wyznaniowych..., s. 211-221; Tenże, Ograniczenia reprezentacji wyznaniowych osób prawnych Kościoła katolickiego, Krakowski Przegląd Notarialny 2016, nr 2, s. 107-138; D. WALENCIK, Opinia prawna w sprawie nabycia osobowości prawnej przez dom zakonny Zgromadzenia Sióstr Najświętszej Rodziny z Nazaretu $z$ siedziba w Żarkach, Przegląd Prawa Wyznaniowego 2011, t. 3, s. 259-268; Tenże, Prawo kanoniczne (wewnętrzne) związków wyznaniowych a prawo polskie, Przegląd Sądowy 2013, nr 5, s. 11-25. 
zgłaszany przez przedstawicieli doktryny postulat wprowadzenia elektronicznego, powszechnego rejestru podmiotów wyznaniowych ${ }^{5}$.

Niniejszy artykuł dotyczy problematyki uczestnictwa kurii diecezjalnej (w Kościołach wschodnich - eparchialnej) jako jednostki organizacyjnej (jednostki wewnętrznej) diecezji (w Kościołach wschodnich - eparchii) albo Kościołów partykularnych prawnie z nią zrównanych w powszechnym obrocie prawnym. Na podstawie analizy obowiązujących przepisów prawa polskiego, ubogaconej poglądami judykatury i doktryny postaram się odpowiedzieć na pytanie: czy kuria diecezjalna w ogóle może być uczestnikiem obrotu prawnego? A jeżeli tak, to w jakim zakresie?

\section{Definicja}

Zgodnie z kan. $469 \mathrm{KPK}^{6}$ kuria diecezjalna ${ }^{7}$ składa się z tych instytucji ${ }^{8}$ i osób, które świadczą biskupowi diecezjalnemu (i tym, którzy są z nim prawnie zrównani) pomoc w zarządzaniu całą diecezją (albo Kościołem partykularnym z nią zrównanym - prałaturą terytorialną, opactwem terytorialnym, administraturą apostolską, prefekturą

\footnotetext{
${ }^{5}$ Por. M. Pietrzak, Prawo kanoniczne..., s. 31; A. Januchowski, Skuteczność prawa kanonicznego..., s. 56-57; Tenże, Wybrane zagadnienia..., s. 234-235. D. WALENCIK, Opinia prawna..., s. 268; Tenże, Kościelne osoby prawne do wykazu elektronicznego, http://www.rp.pl/Opinie/304129969-Koscielne-osoby-prawne-do-wykazu-elektronicznego.html [dostęp: 10 listopada 2017 r.].

${ }^{6}$ Codex Iuris Canonici auctoritate Ioannis Pauli PP. II promulgatus, AAS 75II(1983), s. 1-317; tekst polski w: Kodeks Prawa Kanonicznego przekład polski zatwierdzony przez Konferencję Episkopatu tekst dwujęzyczny, E. Sztafrowski (tłumaczenie) i komisja naukowa pod red. K. Dynarskiego, Poznań 2008; [dalej: KPK].

${ }^{7}$ Poza tym istnieją kurie w instytutach życia konsekrowanego i stowarzyszeniach życia apostolskiego.

${ }^{8}$ J. KRukowski, Komentarz do kan. 469, w: Komentarz do Kodeksu Prawa Kanonicznego, t. II/1 Księga II Lud Boży, cz. I Wierni chrześcijanie, cz. II Ustrój hierarchiczny, red. J. Krukowski, Poznań 2005, s. 345 dokonując tłumaczenia na język polski użył słowa „organów”, chociaż w tekście typicznym - łacińskim posłużono się liczbą mnogą (institutis) rzeczownika institutum, -i, który należy przetłumaczyć jako „instytucja”. Por. A. Jougan, Słownik kościelny łacińsko-polski, wyd. 3, Poznań-Warszawa-Lublin 1958, s. 347.
} 
apostolską, wikariatem apostolskim ${ }^{9}$, ordynariatem wojskowym ${ }^{10}$ ), zwłaszcza w kierowaniu działalnością pasterską, w administrowaniu i wykonywaniu władzy sądowniczej w sposób przewidziany w prawie kanonicznym (kan. $391 \mathrm{KPK})^{11}$.

Biskupi diecezjalni (i ci, którzy są z nimi zrównani) mogą w pewnej mierze dostosowywać skład kurii diecezjalnej (kurii Kościoła partykularnego zrównanego z diecezją) do miejscowych potrzeb i możliwości ${ }^{12}$. KPK określa, które instytucje i osoby powinny wchodzić w jej skład obligatoryjnie oraz które mogą być ustanowione fakultatywnie przez biskupa diecezjalnego (i tych, którzy są z nimi zrównani), uwzględniając rzeczywiste potrzeby i wielkości diecezji (albo Kościoła partykularnego $\mathrm{z}$ nią zrównanego), np. moderatora kurii ${ }^{13}$, radę

\footnotetext{
${ }^{9}$ Por. kan. 370-371 KPK.

${ }^{10}$ Por. Joannes Paulus PP. II, Constitutio apostolica Spirituali militum curae, AAS 78(1986), s. 481-486, tekst polski w: Ustrój hierarchiczny Kościoła. Wybór źródeł, red. W. Kacprzyk, M. Sitarz, Lublin 2006, s. 211-216. Szerzej na ten temat zob. W. Góralski, Struktura duszpasterstwa wojskowego w świetle konstytucji apostolskiej papieża Jana Pawła II Spirituali militum curae z 21 IV 1986 r., Prawo Kanoniczne 32(1989), nr 3-4, s. 143-155; Z. Jaworski, Pozycja ordynariatu wojskowego w Polsce w świetle konstytucji apostolskiej Spirituali militum curae i statutu, Roczniki Nauk Prawnych 16(2006), nr 2, s. 195-207.

${ }^{11}$ Por. kan. 243 Codex Canonum Ecclesiarum Orientalium auctoritate Ioannis Pauli PP. II promulgatus, AAS 82(1990), s. 1033-1363), tekst polski w: Kodeks Kanonów Kościołów Wschodnich promulgowany przez papieża Jana Pawła II, tłumaczenie L. Adamowicz, Lublin 2002; [dalej: KKKW].

${ }^{12}$ Wytyczne w kwestii przyznanej biskupowi diecezjalnemu władzy organizowania kurii w sposób, który uzna za najbardziej odpowiedni zawierają nr 177-178 Dyrektorium Kongregacji ds. Biskupów o pasterskiej posłudze biskupów Apostolorum successores. Por. Congregazione per i Vescovi, Direttorio per il ministero pastorale dei vescovi Apostolorum successores, Città del Vaticano 2004, tekst polski w: Ustrój hierarchiczny Kościoła. Wybór źródeł..., s. 517-711.

${ }^{13}$ Moderator kurii, czyli szef administracyjny kurii, który podlega bezpośrednio biskupowi diecezjalnemu ma pobudzać i koordynować pracę kurii. Dlatego też winien on mieć wiedzę o wszystkich działaniach kurii. Jest on także kierownikiem dla osób wchodzących w skład kurii, również w tym co dotyczy ich relacji pracowniczych, a także samej pracy. Por. Communicationes 5(1973), s. 225-226; J.I. Arrieta, Komentarz do kan. 473-474, w: Kodeks Prawa Kanonicznego. Komentarz, edycja polska na podstawie wydania hiszpańskiego, red. P. Majer, Kraków 2011, s. 411.
} 
biskupią, różne komisje, wydziały czy referaty duszpasterskie ${ }^{14}$. W ramach władzy wykonawczej KPK wyróżnia obligatoryjnie: wikariuszy generalnych i biskupich (kan. 475-481), kanclerza i innych notariuszy (kan. 482-491) oraz diecezjalną radę ds. ekonomicznych i ekonoma (kan. 492-494). Gdy idzie o sprawy i osoby, związane w kurii z wykonywaniem władzy sądowniczej, to należy zachować przepisy księgi VII KPK zatytułowanej „Procesy” (kan. 472), a KPK obligatoryjnie wymienia: wikariusza sądowego, sędziów diecezjalnych, notariuszy, obrońcę węzła i rzecznika sprawiedliwości ${ }^{15}$.

W związku z tym podziałem rodzi się pytanie: czy mamy do czynienia z jedną (kuria diecezjalna), czy dwoma (kuria diecezjalna oraz sąd diecezjalny) instytucjami? Ponieważ część przedstawicieli doktryny uważa sąd diecezjalny za jednostkę odrębną od kurii diecezjalnej, wydaje się konieczne wskazanie na genezę takiego stanowiska. Ksiądz profesor Józef Krukowski twierdzi, iż w Polsce „nazwy »kuria biskupia« zamiast »kuria diecezjalna «16 używa się na oznaczenie tej części »kurii diecezjalnej «, która służy kierowaniu pracą duszpasterską i wykonywaniu władzy administracyjnej; natomiast nazwy »sąd biskupi« używa się na oznaczenie tej części kurii diecezjalnej, która

\footnotetext{
${ }^{14}$ Por. W. Gór Alski, Wydziały i referaty duszpasterskie kurii diecezjalnej, w: Struktura i zadania kurii diecezjalnej, red. J. Krukowski, K. Warchałowski, Warszawa 2003, s. 119-133.

${ }^{15}$ Kan. 243 KKKW jest bardziej precyzyjny i wymienia wprost osoby i gremia wchodzące w skład kurii: „\$2. Do Kurii Eparchialnej należą: protosyncellus, syncellowie, wikariusz sądowy, ekonom eparchialny i rada do spraw ekonomicznych, kanclerz, sędziowie eparchialni, rzecznik sprawiedliwości i obrońca węzła, notariusze $\mathrm{i}$ inne osoby angażowane przez biskupa eparchialnego do należytego wypełnienia obowiązków w kurii eparchialnej”. Wreszcie zawiera normę blankietową zamieszczoną w $\$ 3$ : „Dla zaspokojenia potrzeb lub pożytku eparchii biskup eparchialny może ustanowić w kurii eparchialnej również inne urzędy".

${ }^{16}$ Jak silnie jest to ugruntowany zwyczaj obrazuje treść przepisu art. 55 ust. 5 pkt. 3 ustawy z dnia 17 maja 1989 r. o stosunku Państwa do Kościoła katolickiego w Rzeczypospolitej Polskiej (t.j. Dz. U. z 2019 r., poz. 1347), który stanowi, że zwolnienie od opodatkowania podatkiem od nieruchomości obejmuje nieruchomości lub ich części przeznaczone na cele mieszkalne duchownych i członków zakonu, jeżeli „znajdują się w budynkach kurii diecezjalnych i biskupich”.
} 
służy wykonywaniu władzy sądowej"17. Zdaniem Marii Dębowskiej „taki zwyczaj ukształtował się już w latach międzywojennych, z tym, że wówczas powszechnie używano nazwy »kuria biskupia«, a nie »kuria diecezjalna«, na określenie całej instytucji (piony administracyjny i sądowy). Jednocześnie jednak - zapewne z przyczyn praktycznych tę samą nazwę: »kuria biskupia« przypisano pionowi administracyjnemu tej instytucji. Zwyczaj ten upowszechnił się we wszystkich diecezjach, a nazwa »kuria biskupia « do tego stopnia przylgnęła tylko do sektora administracyjnego kurii diecezjalnej, iż zaczęto uważać sąd biskupi za odrębną instytucję diecezjalną"

Moim zdaniem należy przyjąć, że sąd diecezjalny jest wyodrębnioną jednostką wewnętrzną (instytucją w rozumieniu KPK), ale działającą w ramach kurii diecezjalnej, niemniej rządzi się odrębnymi przepisami. Tym samym w skład kurii diecezjalnej wchodzą osoby i instytucje, które można zakwalifikować do trzech sektorów: jurysdykcyjno-pastoralnego (wikariusz generalny, wikariusz biskupi, kanclerz, notariusz, kancelaria, wydział duszpasterski, katechetyczny, misyjny itp.), administracyjno-ekonomicznego (diecezjalna rada ds. ekonomicznych, ekonom diecezjalny, wydział finansowo-gospodarczy, kadry) i sądowniczego (sąd diecezjalny) ${ }^{19}$. Mianowanie tych, którzy sprawują urzędy kurialne, należy do biskupa diecezjalnego (i tych, którzy są z nimi zrównani), gdyż działają oni w jego imieniu (kan. 470 KPK, kan. $244 \$ 1$ KKKW).

\footnotetext{
${ }^{17}$ J. KRu Kowski, Administracja w Kościele. Zarys kościelnego prawa administracyjnego, Lublin 1985, s. 86.

${ }^{18}$ M. Dęвowska, Wprowadzenie, w: Kurie (archi)diecezjalne Kościoła rzymskokatolickiego w II Rzeczypospolitej, red. M. Dębowska, Lublin 2016, s. 4.

${ }^{19}$ Por. J. Krukowski, Komentarz do kan. 469, w: Komentarz do Kodeksu Prawa Kanonicznego..., s. 345-347.
} 


\section{Osoba prawna, jednostka organizacyjna, podmiot ustawowy, podmiot prawnopodatkowy, aparat pomocniczy}

Nie ulega wątpliwości, że zgodnie z przepisami kodeksu cywilnego ${ }^{20}$ podmiotami stosunków cywilnoprawnych są osoby fizyczne i osoby prawne. Ich atrybutem bowiem jest zdolność prawna. W myśl przepisu art. 33 k.c. osobami prawnymi są Skarb Państwa i jednostki organizacyjne, którym przepisy szczególne przyznają osobowość prawną. Na ogół przyjmuje się, że przyznanie to powinno nastąpić w sposób wyraźny przez nazwanie określonej jednostki organizacyjnej osobą prawną w odnoszących się do niej przepisach. Przyznanie osobowości prawnej wymaga zatem wskazania z nazwy rodzajów lub indywidualnych jednostek organizacyjnych, które uznaje się za osoby prawne ${ }^{21}$.

Otóż kuria diecezjalna nie jest ani imiennie, ani rodzajowo wymieniona wśród kościelnych jednostek organizacyjnych, których osobowość prawną uznano (czy to ex lege czy to po powiadomieniu odpowiedniego organu władzy państwowej) na mocy przepisów ustawy o stosunku państwa do Kościoła katolickiego. Nie jest wymieniona także wśród podmiotów, które mogą uzyskać osobowość prawną, zgodnie z przepisami przywołanej ustawy, poprzez sądową rejestrację (wpis do KRS). Jedyna możliwość, by kuria diecezjalna została wyposażona w atrybut podmiotowości prawnej, to nadanie jej osobowości prawnej przez biskupa diecezjalnego zgodnie z kanonami Księgi I KPK dotyczącymi osób prawnych w Kościele ${ }^{22}$ (erygowanie publicznej kościelnej osoby prawnej i zatwierdzenie jej statutu), a następnie wydanie na mocy art. 10 ustawy o stosunku państwa do Kościoła katolickiego rozporządzenia w tej sprawie przez ministra

\footnotetext{
${ }^{20}$ Ustawa z dnia 23 kwietnia 1964 r. - Kodeks cywilny (t.j. Dz. U. z 2019 r., poz. $1145 \mathrm{z}$ późn. $\mathrm{zm}$.).

${ }^{21}$ Por. uchwały składu siedmiu sędziów SN: z dnia 10 stycznia 1990 r., III CZP 97/89, OSNC 1990, nr 6, poz. 74; z dnia 14 października 1994 r., III CZP 16/94, OSNC 1995, nr 3, poz. 40 oraz z dnia 26 stycznia 1996 r., III CZP 111/95, OSNC 1996, nr 5, poz. 63; uchwała SN z dnia 23 kwietnia 1993 r., III CZP 7/93, OSNC 1993, nr 11, poz. 199.

${ }^{22} \mathrm{~W}$ żadnym miejscu KPK nie wspomina bowiem wprost o osobowości prawnej kurii diecezjalnej, ale też nie wyklucza takiej możliwości.
} 
właściwego ds. wyznań religijnych oraz mniejszości narodowych i etnicznych ${ }^{23}$.

Podział podmiotów stosunków cywilnoprawnych na osoby fizyczne i osoby prawne nie jest podziałem dychotomicznym istnieje bowiem trzecia kategoria podmiotów, zwana „ułomnymi osobami prawnymi”, „niezupełnymi osobami prawnymi” czy "podmiotami ustawowymi" ${ }^{24}$. Na mocy przepisu art. $33^{1} \$ 1$ k.c. do jednostek organizacyjnych niebędących osobami prawnymi, którym ustawa przyznaje zdolność prawną, stosuje się odpowiednio przepisy o osobach prawnych. Tym samym w stosunkach cywilnoprawnych w ograniczonym stopniu mogą uczestniczyć także jednostki organizacyjne, które nie zostały uznane za osoby prawne, ale przepisy ustawy przyznają im zdolność prawną ${ }^{25}$. Do tej grupy mogą być zaliczane jednak tylko takie jednostki, którym zdolność prawną przyznają przepisy ustawy. Mamy zatem do czynienia z normatywną metodą regulacji i zamkniętym

\footnotetext{
${ }^{23} \mathrm{Na}$ temat art. 10 ustawy o stosunku państwa do Kościoła katolickiego zob. B. Rakoczy, Ustawa o stosunku państwa do Kościoła katolickiego. Komentarz, Warszawa 2008, s. 100-103 oraz Instrukcję z dnia 15 czerwca 2000 r. dotyczącą zakresu i sposobu uzyskania osobowości pranej przez instytucje kościelne na podstawie prawa polskiego (art. 4 ust. 3 Konkordatu), https://mswia.gov.pl/download/1/24724/ instrukcja-dotyczaca-art-4-ust-3.pdf [dostęp: 10 listopada 2017 r.].

${ }^{24}$ Por. Z. Świderski, Komentarz do art. 331, w: Kodeks Cywilny - Część Ogólna. Komentarz, red. M. Pyziak-Szafnicka, P. Księżak, wyd. 2, Warszawa 2014, s. 413.

${ }^{25} \mathrm{~W}$ prawie polskim jednostkami organizacyjnymi nieposiadającymi osobowości prawnej są: spółka jawna, spółka partnerska, spółka komandytowa, spółka komandytowo-akcyjna (art. $4 \$ 1$ pkt 1 oraz art. $8 \$ 1$ ustawy z dnia 15 września 2000 r. - Kodeks spółek handlowych - t.j. Dz. U. z 2019 r., poz. 505 z późn. zm.), spółka akcyjna w organizacji, spółka $z$ ograniczoną odpowiedzialnością w organizacji (art. $4 \$ 1$ pkt 2 w związku z art. $11 \$ 1$ k.s.h.), wspólnota mieszkaniowa (art. 6 ustawy z dnia 24 czerwca 1994 r. o własności lokali - t.j. Dz. U. z 2019 r., poz. 737 z późn. zm.), partia polityczna niewpisana do ewidencji (art. 16 ustawy z dnia 27 czerwca 1997 r. o partiach politycznych - t.j. Dz.U. z 2018 r., poz. 580), stowarzyszenie zwykłe (art. 40 ust. 1 i la ustawy z dnia 7 kwietnia 1989 r. - Prawo o stowarzyszeniach - t.j. Dz. U. z 2019 r., poz. 713); oddziały główne zagranicznych zakładów ubezpieczeń (art. 179 ust. 1 ustawy z dnia 11 września 2015 r. o działalności ubezpieczeniowej i reasekuracyjnej - t.j. Dz. U. z 2019 r., poz. 381 z późn. zm.).
} 
katalogiem (numerus clausus) takich jednostek organizacyjnych ${ }^{26}$. Jednostka organizacyjna niebędąca osobą prawną, ale posiadająca zdolność prawną może nabywać prawa i zaciągać zobowiązania, może także pozywać i być pozwaną. Jednostki takie mają zatem zdolność sądową, ale tylko w ramach przyznanej im zdolności prawnej.

Wśród jednostek organizacyjnych, które nie zostały wyposażone z mocy przepisów w przymiot osobowości prawnej, wyróżnić można te, które mają zdolność prawną - czyli mogą być podmiotami praw i obowiązków z zakresu prawa cywilnego oraz te, które zdolności prawnej nie posiadają (są jedynie organizacyjnie wyodrębnione jednostki wewnętrzne). Użyte $w$ art. $33^{1} \$ 1$ k.c. pojęcie „jednostka organizacyjna" $\mathrm{z}$ braku definicji legalnej, nie ma wyraźnie określonej treści. Przyjmuje się jednak powszechnie, że jest to twór społeczny, przejawiający się w postaci zorganizowanej formy działalności ludzkiej, którego funkcjonowanie regulują różne gałęzie prawa ${ }^{27}$. Biorąc pod uwagę to kryterium kuria diecezjalna jest jednostką organizacyjną (jednostką wewnętrzną) diecezji, ale nieposiadającą zdolności prawnej.

Typowymi cechami osobowości prawnej są: struktura organizacyjna, posiadanie majątku, zdolność bycia podmiotem praw i obowiązków materialnoprawnych, zdolność sądowa i procesowa oraz odpowiedzialność własnym majątkiem za zobowiązania. Jeżeli przynajmniej dwie z tych cech charakteryzują określoną konstrukcję prawną, to mamy do czynienia $\mathrm{z}$,ułomną osobą prawną"28. W przypadku kurii diecezjalnej możemy jedynie mówić o strukturze organizacyjnej. Kuria diecezjalna nie jest właścicielem majątku, nie posiada zdolności prawnej, zdolności sądowej i procesowej (z jednym wyjątkiem), nie odpowiada własnym majątkiem za zobowiązania.

\footnotetext{
${ }^{26}$ Szerzej na ten temat M. PAzDAN, Komentarz do art. 331, w: Komentarz do Kodeksu cywilnego, t. I Art. 1-44910, red. K. Pietrzykowski, wyd. 8, Warszawa 2015, s. 161-168 wraz z podaną tam literaturą i orzecznictwem.

${ }^{27}$ Por. uchwała składu siedmiu sędziów SN z dnia 26 stycznia 1996 r., III CZP 111/95, OSNC 1996, nr 5, poz. 63.

${ }^{28}$ Por. uchwała składu siedmiu sędziów SN z dnia 21 grudnia 2007 r., III CZP 65/07, OSNIC 2008, nr 7-8, poz. 69.
} 
Tak więc kuria diecezjalna nie jest także „podmiotem ustawowym”, mimo że może być pracodawcą. I tylko w sprawach z zakresu prawa pracy (o ile jest pracodawcą) może posiadać zdolność sądową i procesową $^{29}$, co nie oznacza jednak przyznania jej zdolności prawnej. Żaden przepis ustawy o stosunku państwa do Kościoła katolickiego (ani żaden inny przepis rangi ustawowej) nie zawiera bowiem unormowań, które przyznawałyby kuriom diecezjalnym zdolność prawną, bądź przymiot organu kościelnej osoby prawnej ${ }^{30}$. Zdolność prawna, a w konsekwencji także zdolność do czynności prawnych, jest cechą normatywną, co oznacza, że może zostać przyznana wyłącznie na podstawie przepisu prawa i to wyłącznie rangi ustawowej.

Wydaje się też, że kuria jako jednostka organizacyjna (jednostka wewnętrzna) nie może być odrębnym podmiotem podatkowym. Otóż zgodnie z przepisem art. 12 ustawy o stosunku państwa do Kościoła katolickiego kościelne wydawnictwa, zakłady wytwórcze, usługowe i handlowe, zakłady charytatywno-opiekuńcze, szkoły i inne placówki oświatowo-wychowawcze, nieposiadające osobowości prawnej, działają w ramach kościelnych osób prawnych, które je powołały. Tylko wymienione wyżej kościelne jednostki organizacyjne (a katalog ten ma charakter zamknięty, mimo że wymienia te jednostki tylko rodzajowo) mogą być na wniosek kościelnej osoby prawnej uznane przez właściwego dyrektora izby administracji skarbowej za odrębne podmioty podatkowe, jeśli są organizacyjnie wyodrębnione (art. 55 ust. 8). W tym enumeratywnym wyliczeniu nie uwzględniono jednak kurii diecezjalnej.

Biskup diecezjalny to nie tylko organ kościelnej osoby prawnej w rozumieniu prawa cywilnego, ale także organ administracji

\footnotetext{
${ }^{29}$ Por. przepis art. $460 \$ 1$ k.p.c., zgodnie z którym zdolność sądową i procesową ma także pracodawca, chociażby nie posiadał osobowości prawnej. Stąd SN w wyroku z dnia 4 stycznia 2008 r., I PK 187/07, https://www.saos.org.pl/judgments/86959 [dostęp: 6 listopada 2017 r.], słusznie przyjął, że art. 64 k.p.c. określający podmioty, którym przysługuje zdolność sądowa, należy analizować łącznie z zawartą w k.p. definicją pracodawcy.

${ }^{30}$ Por. wyrok Sądu Okręgowego w Katowicach z dnia 28 maja 2012 r., XIII GC 94/12/Ap, niepubl.
} 
kościelnej, czyli osoba działająca w sposób władczy na podstawie przepisów prawa w imieniu Kościoła, powołana do realizacji określonych przez prawo kompetencji, polegających najczęściej na zarządzaniu sprawami publicznej kościelnej osoby prawnej - diecezji (funkcja administracyjno-ekonomiczna), załatwianiu spraw wiernych i kształtowaniu ich sytuacji prawnej (funkcja jurysdykcyjno-pastoralna i sądownicza). Od organu administracji trzeba jednak odróżnić jego aparat pomocniczy, czyli zorganizowany zespół instytucji i osób (jednostka organizacyjna), które obsługują organ, umożliwiając mu prawidłowe funkcjonowanie i realizację powierzonych zadań. A zatem kuria diecezjalna to nic innego jak aparat pomocniczy biskupa diecezjalnego ${ }^{31}$.

\section{Zdolność prawna, zdolność do czynności prawnych, zdolność sądowa i procesowa}

Zdolność prawna to zdolność do tego, aby być podmiotem praw i obowiązków z zakresu prawa cywilnego. Osoba prawna, ale i podmiot ustawowy nabywają zdolność prawną z chwilą wpisu do odpowiedniego rejestru, chyba że ustawa stanowi inaczej (art. 37 k.c.). Zdolność prawna może zostać przez jednostkę organizacyjną nabyta również na mocy przepisu ustawy. Jednostki organizacyjne tracą zdolność prawną z chwilą wykreślenia z odpowiedniego rejestru lub zakończenia likwidacji.

Zakres, w jakim można korzystać ze zdolności prawnej, definiuje odrębny atrybut podmiotu prawa - zdolność do czynności prawnych, czyli zdolność do dokonywania we własnym imieniu czynności prawnych, a zatem do przyjmowania i składania oświadczeń woli mających na celu powstanie, zmianę lub ustanie stosunku prawnego.

\footnotetext{
${ }^{31} \mathrm{Na}$ co wskazuje treść przepisów kan. 469 KPK: Kuria diecezjalna składa się $\mathrm{z}$ tych instytucji i osób, które świadczą biskupowi pomoc w zarządzaniu całą diecezją, zwłaszcza w kierowaniu działalnością pasterską, w administrowaniu diecezją i wykonywaniu władzy sądowniczej oraz kan. $243 \$ 1$ KKKW: Biskup eparchialny powinien mieć przy swej stolicy kurię eparchialną, która wspiera go w rządach powierzoną mu eparchią.
} 
Utrata zdolności do czynności prawnych następuje z chwilą ustania zdolności prawnej. Biorąc pod uwagę wcześniejsze ustalenia kurii diecezjalnej co do zasady nie przysługuje ani zdolność prawna, ani zdolność do czynności prawnych.

Z kolei zdolność sądowa to zdolność do występowania w postępowaniu jako strona (art. $64 \$ 1$ k.p.c. ${ }^{32}$ ) lub uczestnik postępowania ${ }^{33}$, zaś zdolność procesowa to możliwość podejmowania czynności procesowych (art. $65 \$ 1$ k.p.c.), takich jak np. wytaczanie powództwa i zaskarżanie orzeczeń sądowych, składanie wszelkiego rodzaju oświadczeń i wniosków, czyli zdolność do działania w procesie we własnym imieniu, osobiście lub przez pełnomocnika. Zdolność sądową ma każda osoba fizyczna i prawna (art. $64 \$ 1$ k.p.c.), a także jednostki organizacyjne niebędące osobami prawnymi, którym ustawa przyznaje zdolność prawną (art. $64 \$ 11$ k.p.c.). Zaś zdolność do czynności procesowych (zdolność procesową) mają osoby fizyczne posiadające pełną zdolność do czynności prawnych, osoby prawne oraz jednostki organizacyjne niebędące osobami prawnymi, którym ustawa przyznaje zdolność prawną (art. $65 \$ 1$ k.p.c.). Jest to regulacja zgodna z założeniami prawa cywilnego materialnego, gdyż przyznana tym podmiotom zdolność sądowa i procesowa stanowi atrybut ich zdolności prawnej. Zdolność procesowa podmiotów, które nie są osobami fizycznymi, jest związana z ich zdolnością sądową, tzn. podmioty te, mając zdolność sądową, mają równocześnie także zdolność procesową. Przy czym osoby prawne posiadają pełną zdolność procesową, która wynika właśnie z ich osobowości prawnej. Osoby prawne oraz jednostki organizacyjne niebędące osobami prawnymi, którym ustawa przyznaje zdolność prawną dokonują czynności procesowych przez swoje organy albo przez osoby uprawnione do działania w ich imieniu (art. 67 k.p.c.).

\footnotetext{
${ }^{32}$ Ustawa z dnia 17 listopada 1964 r. - Kodeks postępowania cywilnego (t.j. Dz. U. z 2019, poz. 1460 z późn. zm.).

${ }^{33}$ Por. J. JodŁowski, Z. Resich, J. Lapierre, T. Misiuk-JodŁowska, K. Weitz, Postępowanie cywilne, wyd. 7, Warszawa 2014, s. 185.
} 
Zgodnie z utrwalonym orzecznictwem Sądu Najwyższego przyjmuje się, że jednostce organizacyjnej osoby prawnej (jednostce wewnętrznej) zdolność sądowa nie przysługuje ${ }^{34}$. Tym samym kurii diecezjalnej jako jednostce organizacyjnej (jednostce wewnętrznej) osoby prawnej - diecezji zdolność sądowa i procesowa nie przysługuje, z wyjątkiem spraw z zakresu prawa pracy (o ile oczywiście kuria jest pracodawcą). A zatem zarówno złożenie pozwu przez kurię diecezjalną, jak i pozwanie kurii diecezjalnej winno skutkować odrzuceniem pozwu. Sąd odrzuci bowiem pozew, jeżeli jedna ze stron postępowania nie ma zdolności sądowej albo jeżeli powód nie ma zdolności procesowej (art. $199 \$ 1$ pkt 3 k.p.c.). Wprawdzie z powodu braku zdolności sądowej jednej ze stron albo zdolności procesowej powoda sąd odrzuci pozew dopiero wówczas, gdy brak ten nie będzie uzupełniony zgodnie z przepisami kodeksu (art. $199 \$ 2$ k.p.c.). W tym celu sąd winien stosować przepisy art. art. 70 i 71 k.p.c. To znaczy, gdy brak jest usuwalny sąd wyznaczyć odpowiedni termin do jego usunięcia i dopiero po upływie wyznaczonego terminu wydać postanowienie o odrzuceniu pozwu. Natomiast w sytuacji, gdy braku tego nie można uzupełnić, sąd powinien odrzucić pozew bez wzywania o uzupełnienie braków, albowiem braków, które są nieusuwalne, nie da się uzupełnić. Przepisy te są do zastosowania na wstępnym etapie rozpoznawania sprawy, a w każdym razie po dostrzeżeniu błędu. Niemniej brak zdolności sądowej po którejkolwiek ze stron procesu albo brak zdolności procesowej powoda stanowi bezwzględną ujemną przesłankę procesową w postępowaniu cywilnym, którą sąd zobowiązany jest uwzględniać z urzędu w każdym etapie sprawy (art. 202 zd 3 k.p.c.). A ponadto brak zdolności sądowej po którejkolwiek ze stron procesu albo brak zdolności procesowej powoda nie może być uzupełniony przez wstąpienie do udziału w sprawie podmiotu posiadającego

\footnotetext{
${ }^{34}$ Por. uchwała składu siedmiu sędziów SN z dnia 14 października 1994 r., III CZP 16/94, OSNC 1995, nr 3, poz. 40; uchwała SN z dnia 11 marca 1994 r., III CZP 21/94, OSNCP 1994, nr 11, poz. 203; uchwała SN z dnia 25 kwietnia 1996 r., II CZP 34/96, OSNC 1996, nr 7-8, poz. 103; postanowienie SN z dnia 28 stycznia 2004 r., IV CK 183/03, niepubl.
} 
tę zdolność (diecezji) zamiast podmiotu, który tej zdolności nie ma (kurii diecezjalnej). Przesłanką warunkującą uzupełnienie tego braku jest zachowanie tożsamości strony dotkniętej tym brakiem, a więc takiego stanu rzeczy, w którym zarówno przed uzupełnieniem, jak i po uzupełnieniu braku zdolności sądowej po którejkolwiek ze stron procesu albo braku zdolności procesowej powoda stroną pozostaje ta sama jednostka organizacyjna ${ }^{35}$. Tym samym, jeżeli pozew wniesiono przeciwko jednostce organizacyjnej nie posiadającej zdolności sądowej albo pozew wniosła jednostka organizacyjna, która nie ma zdolności procesowej, to nie jest możliwe usunięcie tego braku w żaden sposób $^{36}$. Dalsze prowadzenie w tej sytuacji postępowania prowadzi do jego nieważności w rozumieniu przepisu art. 379 pkt 2 k.p.c.

Należy jednak zauważyć, że w trakcie postępowania może mieć miejsce sprostowanie niezupełnego lub wieloznacznego oznaczenia strony, a mylne nazwanie w pozwie strony pozwanej, gdy z przebiegu postępowania widoczne jest, kogo powód miał zamiar pozwać, nie daje samo przez się podstawy do odrzucenia pozwu. W takiej sytuacji może dojść do zmiany oznaczenia strony nie może jednak przy tej okazji dojść do przekształceń podmiotowych powództwa ${ }^{37}$. Możliwe jest także wezwanie przez sąd właściwego podmiotu do udziału $\mathrm{w}$ postępowaniu na mocy przepisu art. $194 \$ 1$ k.p.c. Jednak może ono nastąpić wyłącznie na wniosek strony. Wreszcie możliwe jest sprostowanie oznaczenia strony na podstawie przepisu art. 350 k.p.c. Jest to przepis umożliwiający sądowi pierwszej i drugiej instancji sprostowanie z urzędu w wyroku niedokładności, błędów pisarskich

\footnotetext{
${ }^{35}$ Por. uchwała SN z dnia 19 kwietnia 2001 r., III CZP 10/01, OSNC 2001, nr 10, poz. 147; postanowienie SN z dnia 24 września 2004 r., I CK 131/04, OSNC 2005 nr 9, poz. 156; postanowienie SN z dnia 15 maja 2009 r., II CSK 681/08, LEGALIS nr 265859.

${ }^{36}$ Por. postanowienie SN z dnia 3 października 2002 r., I CKN 448/01, LEX nr 57226; uchwała SN z dnia 19 kwietnia 2001 r., III CZP 10/01, OSNC 2001, nr 10, poz. 147.

${ }^{37}$ Por. postanowienie SN z dnia 25 maja 2007 r., I CSK 30/07, OSNC-ZD 2008, nr B, poz. 33; postanowienie SN z dnia 9 lipca 2009 r., III CZP 45/09, OSNC z 2009, nr 4, poz. 113 .
} 
albo rachunkowych lub innych oczywistych omyłek. Sąd Najwyższy w swych orzeczeniach ${ }^{38}$ przychylał się do jego wykorzystania również wtedy, gdy chodziło o uściślenie oznaczenia strony. Skutkiem sprostowania orzeczenia nie może stać się jednak zmiana podmiotu postępowania $^{39}$.

\section{Kuria diecezjalna jako organ?}

Ksiądz profesor Józef Krukowski twierdzi, że „zgodnie z postanowieniem kan. 469 kuria diecezjalna jest to »zespół organów i osób « (instituta et personae) wspomagających biskupa diecezjalnego w zarządzaniu całą diecezją" ${ }^{40}$. Rodzi się zatem pytanie: czy można zasadnie twierdzić, że kuria diecezjalna jest organem osoby prawnejdiecezji? Kodeks cywilny stoi na stanowisku tzw. teorii organów osoby prawnej. Funkcję organu piastuje jedna lub kilka osób fizycznych, które w sposób przewidziany w ustawie i opartym na niej statucie (art. 38 k.c.), czyli zgodnie z przepisami określającymi ustrój danej osoby prawnej, tworzą i wyrażają w sposób sformalizowany jej wolę. Organ osoby prawnej nie ma zdolności prawnej, nie jest zatem podmiotem stosunków prawnych. Podmiotem tym jest sama osoba prawna. Z tej przyczyny organowi osoby prawnej nie została przyznana zdolność sądowa i nie może występować w procesie cywilnym jako strona (art. $64 \$ 1$ k.c.). Działanie organu (osoby lub grupy osób fizycznych) traktuje się jako działanie osoby prawnej, stąd też wszelkie szkody wyrządzone przez organ przy dokonywaniu czynności w imieniu danej osoby prawnej obciążają osobę prawną, zarówno w stosunkach umownych, jak i pozaumownych. O działaniu jednak osoby prawnej można mówić jedynie wówczas, gdy osoba lub grupa osób fizycznych występują w konkretnej sprawie, w sposób wyraźny lub chociażby

\footnotetext{
${ }^{38}$ Por. wyrok SN z dnia 18 czerwca 1998 r., II CKN 817/97, OSNC 1999, nr 1, poz. 16; postanowienie SN z dnia 4 lutego 2004 r., I CK 342/03, niepubl.; wyrok SN z dnia 22 czerwca 2006 r., V CSK 139/06, nie publ.; postanowienie SN z dnia 8 stycznia 2009 r., I CSK 263/08, niepubl.

${ }^{39}$ Por. postanowienie SN z dnia 16 stycznia 2014 r., IV CSK 214/13, nie publ.

${ }^{40}$ J. Krukowski, Komentarz do kan. 469..., s. 345. Zob. także przypis nr 8.
} 
domniemany, jako organ i w granicach kompetencji tego organu, wynikających z przepisów określających ustrój danej osoby prawnej.

Zgodnie z przepisem art. 7 ust. 3 pkt 3 ustawy o stosunku państwa do Kościoła katolickiego organem diecezji jako osoby prawnej jest biskup diecezjalny albo administrator diecezji. Z unormowaniem tym koresponduje treść kan. 393 KPK, zgodnie z którym we wszystkich czynnościach prawnych diecezji biskup diecezjalny ${ }^{41}$ reprezentuje ją jako osobę. Tak więc to konkretna osoba fizyczna - duchowny pełniący urząd biskupa diecezjalnego albo administratora diecezji piastuje funkcję jednoosobowego organu diecezji jako osoby prawnej. Nie można zatem ani na gruncie prawa cywilnego, ani na gruncie prawa kanonicznego zasadnie twierdzić, że kuria diecezjalna jest organem diecezji jako osoby prawnej, nawet uwzględniając inne rozumienie terminu „organ” w nauce prawa kanonicznego. Otóż w kanonistyce jest on używany jest zamiennie z terminem „urząd”, chociaż to ostatnie jest pojęciem szerszym. Organ to osoba lub zespół osób fizycznych, podejmujących działania władcze w imieniu Kościoła, zgodnie z obowiązującym prawem. Zaś urząd oznacza jakiekolwiek ustanowione na stałe zadanie dla realizacji celu duchowego, czyli dające jakiś udział w misji Kościoła (kan. $145 \mathrm{KPK}$ ). Uwzględniając powyższe znaczenie wskazanych pojęć, można przyjąć, że kuria diecezjalna to zespół organów w rozumieniu kanonistycznym i urzędów kościelnych, jak również ogół środków materialnych i technicznych, pozostających do dyspozycji biskupa diecezjalnego w celu zaradzenia potrzebom wiernych całej diecezji ${ }^{42}$.

Należy zauważyć także, że zgodnie z prawem kanonicznym kościelną osobę prawną (a taką jest np. diecezja) reprezentują, działając w jej imieniu, ci, którym przyznaje to uprawnienie prawo powszechne (tak jest w przypadku biskupa diecezjalnego - kan. 393 KPK) lub

\footnotetext{
${ }^{41}$ Zgodnie zaś z kan. $421 \$ 1$ KPK w ciągu ośmiu dni od uzyskania wiadomości o zawakowaniu stolicy biskupiej, kolegium konsultorów powinno wybrać administratora diecezji, tego mianowicie, który będzie rządził diecezją z zachowaniem przepisu kan. $502 \$ 3$.
}

${ }^{42}$ J.I. Arrieta, Diritto dell'organizzazione ecclesiastica, Milano 1997, s. 369. 
partykularne albo własne statuty; prywatną osobę prawną ci, którym to uprawnienie przyznają statuty (kan. $118 \mathrm{KPK}$ ). Reprezentant osoby prawnej może zatem (tak jest w przypadku biskupa diecezjalnego), ale nie musi być tożsamy z jej organem. Zakres kompetencji reprezentanta osoby prawnej określa prawo (np. kan. $1279 \$ 1,1283-1289$, $1480 \mathrm{KPK})$, statut i ewentualnie pełnomocnictwo.

\section{Kuria diecezjalna jako pracodawca}

Zgodnie z przepisem art. 3 k.p..$^{43}$ pracodawcą jest jednostka organizacyjna, choćby nie posiadała osobowości prawnej, a także osoba fizyczna, jeżeli zatrudniają one pracowników. Sformułowanie „zatrudniają pracowników” należy rozumieć w ten sposób, że wymienione podmioty faktycznie zatrudniają pracowników, a nie, że wykonują w stosunku do nich tylko niektóre czynności z zakresu prawa pracy. Jednostka organizacyjna może być pracodawcą, o ile spełnia następujące przesłanki: jest dopuszczona przez prawo, jest wyodrębniona organizacyjnie i majątkowo oraz ma uregulowany sposób i zakres reprezentacji w stosunkach zewnętrznych, czyli posiada zdolność do zawierania umów o pracę. Nie będzie natomiast pracodawcą jednostka organizacyjna, która jest samodzielna w sensie wykonywania określonych zadań, ale nie ma zdolności do nawiązywania stosunków pracy we własnym imieniu. Dla uznania danej jednostki organizacyjnej za pracodawcę nie jest konieczne pełne wyodrębnienie majątkowe, wiążące się m.in. z prawem własności. Wystarczy prawo dysponowania środkami niezbędnymi do zatrudniania pracowników. Dana jednostka nie musi też posiadać wystarczających środków materialnych na pokrycie swych zobowiązań wobec pracowników. Co więcej, dana jednostka organizacyjna, aby być pracodawcą nawet nie musi posiadać zakładu pracy w znaczeniu przedmiotowym $^{44}$, tj. jednostki techniczno-organiznacyjnej będącej

\footnotetext{
${ }^{43}$ Ustawa z dnia 26 czerwca 1974 - Kodeks pracy (t.j. Dz. U. z 2019 r., poz. 1040 z późn. zm.).

${ }^{44}$ Pod to pojęcie podpadają wszelkie jednostki produkcyjne (zakłady), punkty handlowe (sklepy) i usługowe, warsztaty, biura, itp.
} 
placówką zatrudnienia, w której odbywa się proces pracy (art. 104 $\$ 1,128 \$ 1,207 \$ 1$ k.p.), wystarcza fakt, że zatrudnia chociaż jednego pracownika ${ }^{45}$. Wprawdzie w treści przepisu art. 3 k.p. użyto liczby mnogiej - zatrudniają pracowników. „Kierując się jednak argumentacją a fortiori oraz wykładnią celowościową w formule minus dixit quam voluit, należy objąć zakresem podmiotowym tego przepisu także pracodawców zatrudniających jednego pracownika, niezależnie od wymiaru etatu, na jakim jest on zatrudniony w stosunku pracy ${ }^{46}$.

Nie ma znaczenia także forma prawna. Pracodawcą bowiem może być jednostka organizacyjna nieposiadająca osobowości prawnej i to niezależnie od tego czy posiada ona zdolność prawną i zdolność do czynności prawnych ${ }^{47}$. Tak więc pracodawcą może być podmiot, który nie będzie miał przymiotu podmiotu prawa na gruncie innych dziedzin prawa ${ }^{48}$, np. zrzeszenia producentów, komitety społeczne itp. Za pracodawcę będącego jednostką organizacyjną czynności w sprawach z zakresu prawa pracy dokonuje osoba lub organ zarządzający tą jednostką albo inna wyznaczona do tego osoba (art. $3^{1}$ k.p.). Kuria diecezjalna może zatem być pracodawcą i zakładem pracy nie będąc jednocześnie jednostką organizacyjną posiadającą zdolność prawną (podmiotem ustawowym).

Pracodawca może, ale nie musi być przedsiębiorcą. Zgodnie z przepisem art. 4 ust. 1 ustawy z dnia 2 lipca 2004 r. o swobodzie działalności gospodarczej ${ }^{49}$ przedsiębiorcą w rozumieniu tej ustawy

\footnotetext{
${ }^{45}$ Szerzej na ten temat zob. M. Piankowski, Pracodawca jako jednostka organizacyjna i strona stosunku pracy, Gdańskie Studia Prawnicze 2005, t. 14, s. 956 i nast.; P. WĄż, Koncepcja pracodawcy rzeczywistego w świetle art. 3 k.p., Monitor Prawa Pracy 2007, nr 3, s. 124 i nast.; T. Liszcz, Prawo pracy, wyd. 11, Warszawa 2016, s. 122-123.

${ }^{46}$ K.W. BARAN, Pracodawca jako strona w postępowaniu w sprawach $z$ zakresu prawa pracy, Studia Iuridica Lublinensia 2015, t. 34, s. 113.

${ }^{47}$ M. Lewandowicz-Machnikowska, Stosunek pracy, w: Prawo pracy i ubezpieczeń społecznych, red. K.W. Baran, wyd. 2, Warszawa 2017, s. 193.

${ }^{48}$ M. WujCzy K, Podmioty prawa pracy, w: System Prawa Pracy, t. I Część ogólna, red. K.W. Baran, Warszawa 2017, s. 440.

${ }^{49}$ T.j. Dz. U. z 2017 r., poz. 2168 z późn. zm.
} 
jest osoba fizyczna, osoba prawna i jednostka organizacyjna niebędąca osobą prawną, której odrębna ustawa przyznaje zdolność prawną - wykonująca we własnym imieniu działalność gospodarczą. Za przedsiębiorców uznaje się także wspólników spółki cywilnej w zakresie wykonywanej przez nich działalności gospodarczej (ust. 2). Zaś zgodnie z przepisem art. $43^{1}$ k.c. przedsiębiorcą jest osoba fizyczna, osoba prawna i jednostka organizacyjna, o której mowa w art. $33^{1}$ $\$ 1$ k.c., prowadząca we własnym imieniu działalność gospodarczą lub zawodową. Nie ulega wątpliwości, że zgodnie z tymi przepisami kuria diecezjalna nie może być uznana za przedsiębiorcę. Jednakże w świetle przepisu art. 2 ustawy z dnia 16 kwietnia 1993 r. o zwalczaniu nieuczciwej konkurencji ${ }^{50}$ już tak. Przedsiębiorcami w rozumieniu tej ustawy są bowiem osoby fizyczne, osoby prawne oraz jednostki organizacyjne nie mające osobowości prawnej, które prowadząc, chociażby ubocznie, działalność zarobkową lub zawodową uczestniczą w działalności gospodarczej.

\section{Kuria diecezjalna jako płatnik, wyręczyciel}

Zgodnie z przepisem art. 4 ust. 2 lit. f ustawy z dnia 13 października 1998 r. o systemie ubezpieczeń społecznych ${ }^{51}$ płatnikiem składek ubezpieczeniowych jest duchowny niebędący członkiem zakonu albo przełożony domu zakonnego lub klasztoru w stosunku do członków swych zakonów lub, za zgodą Zakładu Ubezpieczeń Społecznych, inna zwierzchnia instytucja diecezjalna lub zakonna w stosunku do duchownych objętych tą zgodą. Tak wiec kuria diecezjalna jako zwierzchnia instytucja diecezjalna może być za zgodą ZUS płatnikiem składek ubezpieczeniowych dla duchownych - księży diecezjalnych, zwłaszcza pełniących posługę w tej instytucji.

Zobowiązanie podatkowe, z mocy prawa obciążające podatnika, ze względu na jego osobisty charakter może zostać uregulowane wyłącznie przez samego podatnika. Niedopuszczalne i nieskuteczne jest zawarcie umowy cywilnoprawnej przenoszącej obowiązek zapłaty

\footnotetext{
${ }^{50}$ T.j. Dz. U. z 2019 r., poz. 1010 z późn. zm.

${ }^{51}$ T.j. Dz. U. z 2019 r., poz. 300 z późn. zm.
} 
podatku na podmiot inny niż podatnik. Wniosek taki potwierdzają przepisy art. 59-61 ustawy z dnia 29 sierpnia 1997 r. - Ordynacja podatkowa ${ }^{52}$ wskazujące sposoby wygaśnięcia zobowiązań podatkowych, spośród których podstawowe znaczenie ma zapłata podatku (art. $59 \$ 1$ pkt 1 o.p.). Także przepisy określające formę, w jakiej zapłata zobowiązania podatkowego powinna nastąpić, akcentują powiązanie obowiązku zapłaty z osobą podatnika. Jest to szczególnie wyraźne w przypadku zobowiązań związanych z prowadzeniem działalności gospodarczej, dla których podstawową formą płatności jest postać bezgotówkowa, przelewem $\mathrm{z}$ rachunku należącego do podatnika, prowadzonego przez instytucję finansową (art. $61 \S 1$ w związku z art. $60 \$ 1$ pkt 2 o.p. $)^{53}$.

W stanie prawnym obowiązującym do końca 2015 r. przyjmowało się powszechnie, mimo że przepisy nie przewidywały wprost takiego rozwiązania, iż zapłaty podatku, której skutkiem było wygaśniecie zobowiązania podatkowego mógł dokonać za podatnika inny podmiot, pod warunkiem, iż wpłacający złożył pisemne oświadczenie, że działał jako „posłaniec” lub „wyręczyciel” ${ }^{4}$ czy „przekaziciel środków

\footnotetext{
${ }^{52}$ T.j. Dz. U. z 2019 r., poz. 900 z późn. zm.

${ }^{53}$ Por. uchwała składu siedmiu sędziów NSA z dnia 26 maja 2008 r., I FPS 8/07, http://orzeczenia.nsa.gov.pl/doc/B6E80B0298 [dostęp: 6 listopada 2017 r.]. W uchwale tej NSA jednoznacznie stwierdził, że „obowiązek zapłaty podatku wynika ze zobowiązania podatkowego, a zobowiązanym do jego zapłacenia jest podatnik. Tym samym za słuszną należy uznać tezę, że tylko zapłata podatku przez podatnika prowadzi do realizacji zobowiązania podatkowego i tym samym do jego wygaśnięcia”. NSA zaznaczył jednak, że wpłata przez osobę trzecią kwoty odpowiadającej kwocie podatku może być uznana za skuteczną zapłatę podatku, gdy „osoba wpłacająca podatek dokonuje tego ze środków powierzonych mu przez podatnika. Dokonuje wówczas czynności technicznej - wpłaca podatek za podatnika”, ale „zapłaty w sensie prawnym dokonuje podatnik”. W takiej sytuacji nastąpiło wygaśnięcie zobowiązania podatkowego podatnika w trybie art. $59 \$ 1$ pkt 1 o.p.

${ }^{54}$ Tak B. BrzezıŃski, Komentarz do art. 59, w: B. Brzeziński, M. Kalinowski, M. Masternak, A. Olesińska, Ordynacja podatkowa. Komentarz, Toruń 2007, s. 422.
} 
podatnika"55, tj. podmiot pośredniczący w technicznej czynności zapłaty podatku i dokonywał zapłaty zobowiązania ze środków finansowych danego podatnika ${ }^{56}$. W przypadku wpłat systematycznych, oświadczenie takie musiało zawierać informację, że wszystkie wpłaty dokonywane za podatnika pochodzą ze środków finansowych podatnika. Wyręczycielem mógł być np. pracownik podatnika, który na polecenie podatnika płacił podatek w kasie organu podatkowego, lub inna osoba, w tym osoba prawna, jednostka organizacyjna, której podatnik powierzył własne środki z poleceniem zapłaty podatku w imieniu podatnika ${ }^{57}$.

${ }^{55}$ Tak B. DAUter, Komentarz do art. 59, w: S. Babiarz, B. Dauter, B. Gruszczyński, R. Hauser, A. Kabat, M. Niezgódka-Medek, Ordynacja podatkowa. Komentarz, Warszawa 2007, s. 286.

${ }^{56}$ Por. http://interpretacja-podatkowa.pl/interpretacja/pokaz/21-ordynacja-podatkowa/25-zobowiazania-podatkowe/65-wygasniecie-zobowiazan-podatkowych/172-warunki-wygasniecia/156763-poslaniec-przelew-bankowy-spolka-komandy towa-spolka-osobowa-wspolnik-zaliczka-na-podatek-zaplata-podatku-zobowiazanie-podatkowe.html [dostęp: 6 listopada 2017 r.].

${ }^{57}$ Por. wyrok WSA w Warszawie z dnia 12 marca 2010 r., III SA/Wa 2000/09, http://orzeczenia.nsa.gov.pl/doc/5460949014) [dostęp: 6 listopada 2017 r.]: „(...) nie można zapominać, że czym innym jest umowne przenoszenie zobowiązania (długu w zakresie obowiązku zapłaty), które w przypadku zobowiązań podatkowych jest niedopuszczalne, a czym innym dokonanie technicznych czynności wpłaty środków pieniężnych przez podmiot inny niż podatnik tzw. wyręczyciela. Takie działanie podatnika jest w obecnym stanie prawnym dopuszczalne. Działanie podatnika wyręczającego się w czynnościach zapłaty inną osobą z punktu widzenia prawa podatkowego jest indyferentne, gdyż jest jedynie działaniem faktycznym (...). Obowiązek zapłaty podatku cały czas obciąża podatnika, a działania wyręczycieli są traktowane jak działanie samego podatnika. W sensie prawnym zapłaty dokonuje podatnik”. Dalej w wyroku sąd podkreślił, że „dla dopuszczalności posłużenia się przez podatnika wyręczycielem bez znaczenia jest w jakiej formie - gotówkowej czy bezgotówkowej - zapłata następuje. Powierzenie środków pieniężnych na zapłatę podatku możliwe jest bowiem nie tylko poprzez fizyczne przekazanie gotówki „,do ręki” wyręczyciela; ale może także polegać na zadysponowaniu środkami przysługującymi podatnikowi złożonymi na rachunku bankowym spółki komandytowej". 
Od 1 stycznia 2016 r. dodano do Ordynacji podatkowej nowy przepis art. $62 \mathrm{~b}$ ust. $1^{58}$ wprowadzający możliwość zapłaty zobowiązania podatkowego przez inny podmiot niż podatnik. Zgodnie z tym przepisem zapłata podatku może nastąpić przez:

- najbliższych członków rodziny, tj.: małżonka podatnika, jego zstępnych, wstępnych, pasierba, rodzeństwo, ojczyma i macochę - bez ograniczenia wysokości opłacanego zobowiązania podatkowego,

- aktualnego właściciela przedmiotu hipoteki przymusowej lub zastawu skarbowego, jeżeli podatek zabezpieczony jest hipoteką przymusową lub zastawem skarbowym;

- $\quad$ przez inny podmiot, ale wyłącznie, gdy kwota podatku nie przekracza $1000 \mathrm{zł}$.

Przepis ust. 2 wskazanego artykułu o.p. zawiera domniemanie prawne uiszczenia podatku ze środków należących do podatnika, jeżeli tylko treść dowodu zapłaty nie budzi wątpliwości co do przeznaczenia zapłaty na zobowiązanie podatnika. Co w konsekwencji powoduje, że nie ma praktycznego znaczenia to, z czyich środków - podatnika czy podmiotu dokonującego wpłaty - regulowany jest podatek. Ponadto zgodnie z ust. 3 art. 62b o.p. przepisy dotyczące zapłaty podatku przez podatnika stosuje się odpowiednio, co oznacza, że zapłata podatku przez podmiot wymieniony w ust. 1 tego artykułu o.p. skutkuje wygaśnięciem zobowiązania podatkowego.

Niemniej powstała wątpliwość, czy po 1 stycznia 2016 r. dopuszczalna jest nadal zapłata podatku przez wyręczyciela czy też przeciwnie, skutkiem ubocznym nowelizacji o.p., mającej ułatwić wpłacanie podatku przez podmioty inne niż podatnik, jest eliminacja tej instytucji z obrotu prawnego? Ministerstwo Finansów w odpowiedzi z dnia 6 kwietnia 2016 r. udzielonej „Gazecie Prawnej” wyjaśniło, że w obecnym stanie prawnym, poza przypadkami wymienionymi $\mathrm{w}$ art. $62 \mathrm{~b}$ o.p., zapłata podatku $\mathrm{z}$ rachunku bankowego innego podmiotu nie jest w ogóle możliwa. Dla dopuszczalności zapłaty podatku

\footnotetext{
${ }^{58}$ Ustawa z dnia 10 września 2015 r. o zmianie ustawy - Ordynacja podatkowa oraz niektórych innych ustaw (Dz. U. z 2015 r., poz. 1649).
} 
przez inny podmiot niż podatnik nie ma żadnego znaczenia kwestia występowania w charakterze posłańca (wyręczyciela) ${ }^{59}$. Tym samym kuria diecezjalna nie może dokonać zapłaty podatku z rachunku bankowego za jakiegokolwiek podatnika (np. parafię, osobę duchowną), nawet gdyby kwota podatku nie przekraczała 1 tys. zł, ponieważ zgodnie z przepisami art. 49 i 59 ustawy z dnia 29 sierpnia 1997 r. - Prawo bankowe $^{60}$ nie może być stroną umowy rachunku bankowego ${ }^{61}$.

\footnotetext{
${ }^{59}$ Por. http://www.gazetapodatkowa.gofin.pl/minister-finansow-wyjasnia,artykul, 152853.html; [dostęp: 7 listopada 2017 r.]; https://interpretacje-podatkowe.org/zaliczka-na-podatek/ippbl-4511-704-16-6-ks [dostęp: 7 listopada 2017 r.].

${ }^{60}$ T.j. Dz. U. z 2019 r., poz. 2357 z późn. zm.

${ }^{61}$ Art. 49
}

ust. 1: Banki mogą prowadzić w szczególności następujące rodzaje rachunków bankowych:

1) rachunki rozliczeniowe, w tym bieżące i pomocnicze oraz prowadzone dla nich na zasadach określonych w rozdziale 3 a rachunki VAT;

2) rachunki lokat terminowych;

3) rachunki oszczędnościowe, rachunki oszczędnościowo-rozliczeniowe, w tym rachunki rodzinne, oraz rachunki terminowych lokat oszczędnościowych;

4) rachunki powiernicze.

ust 2: Rachunki rozliczeniowe oraz rachunki lokat terminowych mogą być prowadzone wyłącznie dla:

1) osób prawnych;

2) jednostek organizacyjnych nieposiadających osobowości prawnej, o ile posiadają zdolność prawną;

3) osób fizycznych prowadzących działalność zarobkową na własny rachunek, w tym dla osób będących przedsiębiorcami.

ust. 3: Rachunki oszczędnościowe, rachunki oszczędnościowo-rozliczeniowe oraz rachunki terminowych lokat oszczędnościowych mogą być prowadzone wyłącznie dla:

1) osób fizycznych;

2) szkolnych kas oszczędnościowych;

3) pracowniczych kas zapomogowo-pożyczkowych;

4) rad rodziców.

Art. 59

ust. 1: Na rachunku powierniczym mogą być gromadzone wyłącznie środki pieniężne powierzone posiadaczowi rachunku - na podstawie odrębnej umowy - przez osobę trzecią. 


\section{Wnioski}

Zawarte w artykule analizy prowadzą do wniosku, że kuria diecezjalna (w Kościołach wschodnich - eparchialna) jest jednostką organizacyjną (jednostką wewnętrzną) diecezji (w Kościołach wschodnich - eparchii) albo Kościołów partykularnych prawnie zrównanych $\mathrm{z}$ diecezją oraz stanowi aparat pomocniczy biskupa diecezjalnego (albo tych, którzy prawnie są z nim zrównani). Kuria diecezjalna nie jest osobą prawną, chociaż zarówno przepisy prawa kanonicznego, jak i prawa polskiego przewidują możliwość nadania jej osobowości prawnej przez biskupa diecezjalnego zgodnie z kanonami Księgi I KPK dotyczącymi osób prawnych w Kościele (erygowanie publicznej kościelnej osoby prawnej i zatwierdzenie jej statutu), a następnie wydanie na mocy art. 10 ustawy o stosunku państwa do Kościoła katolickiego rozporządzenia w tej sprawie przez ministra właściwego ds. wyznań religijnych oraz mniejszości narodowych i etnicznych.

Kuria diecezjalna nie jest właścicielem majątku, nie posiada ani zdolności prawnej i zdolność do czynności prawnych, ani zdolności sądowej i procesowej (z jednym wyjątkiem), nie odpowiada własnym majątkiem za zobowiązania. Nie jest zatem także „podmiotem ustawowym” czy „ułomną osobą prawną”, mimo że może być pracodawcą i zakładem pracy, tj. placówką zatrudnienia, w której odbywa się proces pracy. I tylko w sprawach z zakresu prawa pracy (o ile jest pracodawcą) może posiadać zdolność sądową i procesową, co nie oznacza jednak przyznania jej zdolności prawnej. Kuria diecezjalna jako jednostka organizacyjna (jednostka wewnętrzna) nie może być odrębnym podmiotem podatkowym, o którym mowa w art. 55 ust. 8 w związku z art. 12 ustawy o stosunku państwa do Kościoła katolickiego. Niemniej jako zwierzchnia instytucja diecezjalna może być za zgodą ZUS płatnikiem składek ubezpieczeniowych dla duchownych księży diecezjalnych, zwłaszcza pełniących posługę w tej instytucji. Nie może natomiast być wyręczycielem.

ust. 2: Stronami umowy rachunku powierniczego są bank i posiadacz rachunku (powiernik). 
Kuria diecezjalna nie jest organem diecezji jako osoby prawnej. Jest to zespół organów i urzędów kościelnych, jak również ogół środków materialnych i technicznych, pozostających do dyspozycji biskupa diecezjalnego (organu diecezji) w celu zaradzenia potrzebom wiernych całej diecezji.

\section{The diocesan curia as a participant of general legal transactions?}

This article discusses issues related to a participation of the diocesan curia in general legal transactions regulated by Polish law. On the basis of analysis of the binding legal norms supported by views of jurisprudence and the doctrine the paper answers the following question: can the diocesan curia participate in legal transactions, and if so, to what extent?

Analyses presented in the article lead to the conclusion, that the diocesan curia (in the Eastern churches - the eparchial one) is an organizational unit (an internal unit) of the diocese (in the Eastern Churches - eparchy unit) or particular Churches legally equal to a diocese and is an auxiliary apparatus to a diocesan bishop (or to legally equal individuals). The diocesan curia is not a legal entity, although both canon law and Polish law assume the possibility to grant it legal personality.

The diocesan curia is not a property owner, has no legal capacity and capacity to perform acts in law as well as capacity to be a party in court proceedings and capacity to perform actions in court proceedings (with one exception) and has no unlimited liability. The body, therefore, is neither a „statutory entity” nor a "legal entity with limited legal capacity”, although it can an employer and a workplace i.e. employment establishment in which work is performed. It is only within labour law, provided it is an employer, that it may have capacity to be a party in court proceedings and capacity to perform actions in court proceedings, which is not equal to granting the diocesan curia legal capacity.

The diocese curia as an organizational unit (internal unit) can not be a separate tax entity. However, as a supreme diocesan institution can be, with consent of the Social Security Office, a payer of security premiums for the clergy - diocesan priests working for this institution. It can not, however, be a substitute. The diocesan curia is not a body of a diocese as a legal entity. It is a body of ecclesial institutions and offices within the 
disposal of a diocesan bishop (a diocesan body) created to meet the needs of the faithful of a given diocese.

SŁOWA KLUCZOWE: kuria diecezjalna; obrót prawny; jednostka organizacyjna; prawo kanoniczne; prawo polskie

KEYWORDS: diocesan curia; legal transactions; organizational unit; canon law; Polish law

\section{Nota o Autorze:}

Ks. Dr hab. Dariusz Walencik, Prof. UO - profesor w Zakładzie Prawa Konstytucyjnego i Wyznaniowego WPiA UO; członek Stowarzyszenia Kanonistów Polskich oraz założyciel i wiceprezes Polskiego Towarzystwa Prawa Wyznaniowego; ekspert Konferencji Episkopatu Polski i Kościelnej Komisji Konkordatowej; autor kilkudziesięciu artykułów, haseł encyklopedycznych, sprawozdań i recenzji w publikacjach zbiorowych oraz periodykach naukowych. 